\title{
Toxicological effect of zinc on liver of broiler chicks
}

\author{
Sabina Khanam
}

\begin{abstract}
Background: The objective of this study is to examine the toxic effects of zinc on the liver of broiler chicks. For this purpose, twenty broiler chicks were taken for the experiment and their weight ranging from 35-45 g. They were divided into four groups: one control and three treated groups. All treated groups were supplemented with 300 mg/kgb.w (low dose, LD), 600 mg/kgb.w (intermediate dose, ID) and 900 mg/kgb.w. (high dose, HD) of Zinc and the control group was fed basal commercial starter diet for 21 days.

Results: Necrosis, liver cell hypertrophy, fuzzy liver cells and lymphocytic inflammation were found in birds exposed to the low and intermediate dose as compared to the controlled group. Broiler chicks exposed to high dose showed pronounced changes in the liver such as congestion of blood vessels, connective tissue hyperplasia, bile duct proliferation, dilation of sinusoids, damaged intercellular contacts between hepatocytes, liver cell hypertrophy and accumulation of inflammatory cells

Conclusion: After the careful analysis of the study, the results have been reported that if one can take zinc in higher amount as supplements or in their foods than it affects the normal structure of the liver and it will alter the functioning of the liver in both human and animals.
\end{abstract}

Keywords: Zinc, Liver, Broiler chicks

\section{Background}

Zinc is a naturally occurring trace element and it is ubiquitous in the environment. The average concentration of zinc in the earth's crust is about $70 \mathrm{mg} / \mathrm{kg}$. Zinc is not available in the environment in its free form, but it is available with the various elements such as zinc carbonate, zinc oxide, zinc sulphide and zinc chloride. The mining activities and metal smelters are primary sources of zinc $[3,23]$. Even it can be produced in the pure form by the electrolytic process. The normal concentration of zinc in plants and vegetables is about 15 to $100 \mathrm{mg} / \mathrm{kg}$ because zinc ions are strongly adsorbed to the soil which is taken up by the plants. Zinc compounds are used as catalysts, fertilizers, batteries, photographic paper, textiles, medical, household applications, cosmetics, paints, plastics and as nutritional supplements $[4,10,13]$.

Correspondence: sabinakhanam@ymail.com

Department of Biological Sciences, Yobe State University, Damaturu, Nigeria
Zinc is an essential nutritionally indispensable element for human, animals and plants because it plays an important role in various biological processes of all living organisms. It is important for growth, bone development, protein synthesis, gene transcription, cell division and for a strong immune system. Therefore, the United Nations considered zinc as "Life Saving Commodity". Zinc also plays an important role in carbohydrate metabolism because it is incorporated into insulin. Due to the deficiency of it in the human body, it leads to a decrease in insulin, which further cause impaired glucose tolerance $[8,9]$. Milk products, meat, nuts and grains are the main sources of zinc for the human body.

It is also essential for birds because it helps in their normal growth, feathering, hormone production, bone development, protein synthesis, nucleic acid synthesis, reproductive performance and for normal metabolic functioning of biochemical enzymes [14].

(c) The Author(s). 2020 Open Access This article is licensed under a Creative Commons Attribution 4.0 International License, which permits use, sharing, adaptation, distribution and reproduction in any medium or format, as long as you give appropriate credit to the original author(s) and the source, provide a link to the Creative Commons licence, and indicate if changes were made. The images or other third party material in this article are included in the article's Creative Commons licence, unless indicated otherwise in a credit line to the material. If material is not included in the article's Creative Commons licence and your intended use is not permitted by statutory regulation or exceeds the permitted use, you will need to obtain permission directly from the copyright holder. To view a copy of this licence, visit http://creativecommons.org/licenses/by/4.0/. 
Low zinc concentration may cause decreased growth, feed intake, and less production of insulin-like growth factor-I, growth hormone binding protein and growth hormone receptor. Generally, zinc is used in poultry diets in the form of inorganic feed-grade zinc, zinc chloride, zinc oxide, or in the form of organic acid and amino acid chelate. Nanoparticles of zinc oxide are also used in poultry diets as a feed additive. These nanoparticles fulfil all the basic requirements of the body by promoting the growth and feed efficiency. It also improved the levels of total protein, glucose, cholesterol and albumin [5, 12, 19, $24,25]$. There are some zinc compounds such as zinc phosphide that is widely used in insecticides and rodenticides which are highly toxic to birds, fish and some non-targeted mammalian species. Various workers studied that ingestion of metal phosphides may cause hepatic damage and acute liver failure, which leads to biochemical and histopathological alterations [20, 22].

The purpose of this study is to determine the toxic effects of zinc on the liver of broiler chicks.

\section{Methods \\ Ethical statement}

Animal studies were conducted according to the regulations of the Institute Animal Ethics Com mittee (IAEC). Registration no.: 34/1999/CPCSEA, ID no.: CDRI-Tox/ SYS/2008/01.

\section{Study design}

The experiment was conducted in the Laboratory of Reproductive Biology, D.G. College, Kanpur and Animal House of Central Drug Research Institute (CDRI), Lucknow.

Broiler chicks were quarantined for 10 days and it was confirmed that they were free of pathogen and any other disease.

Broiler chicks were kept in conventional condition (open system) and housed in stainless steel cages $(800 \times$ $\left.14 \mathrm{~cm}^{2}\right)$ in an animal house with room temperature $22 \pm$ $3{ }^{\circ} \mathrm{C}$, relative humidity $50-70 \%$, photo period of $12 \mathrm{~h}$. light and $12 \mathrm{~h}$ dark. They were provided with commercial broiler chick starter diet and water ad libitum.

\section{Experimental procedure}

Twenty chicks were distributed into four groups randomly with one control group (five chicks) and three treated groups, i.e., low (five chicks), intermediate (five chicks), high (five chicks) dose group in the experiment. The chicks were distributed so as the average body weight of each group remains approximately the same.

This experiment was conducted to determine the toxic effects of Zinc on histopathology of the liver of broiler chicks of various levels of Zinc added to the diet of chicks. Control group was fed on the basal diet (commercial broiler chick starter diet) while all treated groups were supplemented with $300 \mathrm{mg} / \mathrm{kgb.w}$ (low dose, LD), $600 \mathrm{mg} / \mathrm{kgb.w}$ (intermediate dose, ID), and $900 \mathrm{mg} / \mathrm{kgb.w}$. (high dose, HD) of zinc for 21 days.

\section{Experimental animals}

Twenty day-old broiler chicks (Gallus gallus) of Caribro breed weight ranging from 35-45 g, were used in the experiment. Broiler chicks were purchased from Gajaria farm, Lucknow.

\section{Chemical used}

The experimental animals were fed with zinc, in the form of zinc dust or zinc powder. It is a bluish-grey coloured pure metal powder. It is insoluble in water with boiling point $907^{\circ} \mathrm{C}$ and melting point $419^{\circ} \mathrm{C}$.

\section{Sacrifice}

After collecting the tissues the animals (20/20) were decapitated by anaesthesia using Ketamine of dose $0.1 \mathrm{ml} /$ $20 \mathrm{gm}$ in the morning by $11 \mathrm{AM}$ in the laboratory.

\section{Histopathological studies}

Histopathology refers to the microscopic examination of tissue in order to study the manifestations of disease. Systemic studies of the compound were analysed by standard histopathological techniques. Liver was taken for histopathological studies and kept in normal saline solution. After weighing, the organ transferred into a formal saline solution for $72 \mathrm{~h}$, for fixation of tissue. Tissue kept in formal saline is taken out and kept in running tap water for 1-2 h. After washing, 4 to $5 \mathrm{~mm}$ small slices of tissue were taken and dehydrated with acetone and benzene. After dehydration, tissues were embedded with paraffin wax and blocks were prepared on block making work station SHANDON HISTOCENTRE-2. Surplus wax was removed by trimming. After trimming blocks were kept in ice and $0.5 \mu$ thin microtomical sections were cut and the ribbon was formed by LEICA RM2155 MICROTOME. Float the section on a water bath (temp. $43-47^{\circ} \mathrm{C}$ ) and removed the wrinkle. Immersed the albumenized slide in the water and brought the sections gently on to the centre of the slide. Kept the slide on a slide warmer (temp. $43-47^{\circ} \mathrm{C}$ ) till the water was removed.

After section cutting, the sections were stained with haematoxylin and eosin stain. The process of staining is:

I. Put the slides in a slide carrier.

II. Then put those slides in jars containing xylene for 2 changes of 5 min each (Deparaffinization)

III. Transferred the tissue in absolute alcohol for $5 \mathrm{~min}$.

IV. Dehydrated the tissue in descending concentration of ethanol viz 90\%, 70\%, 50\%, 30\% each change of $5 \mathrm{~min}$. 


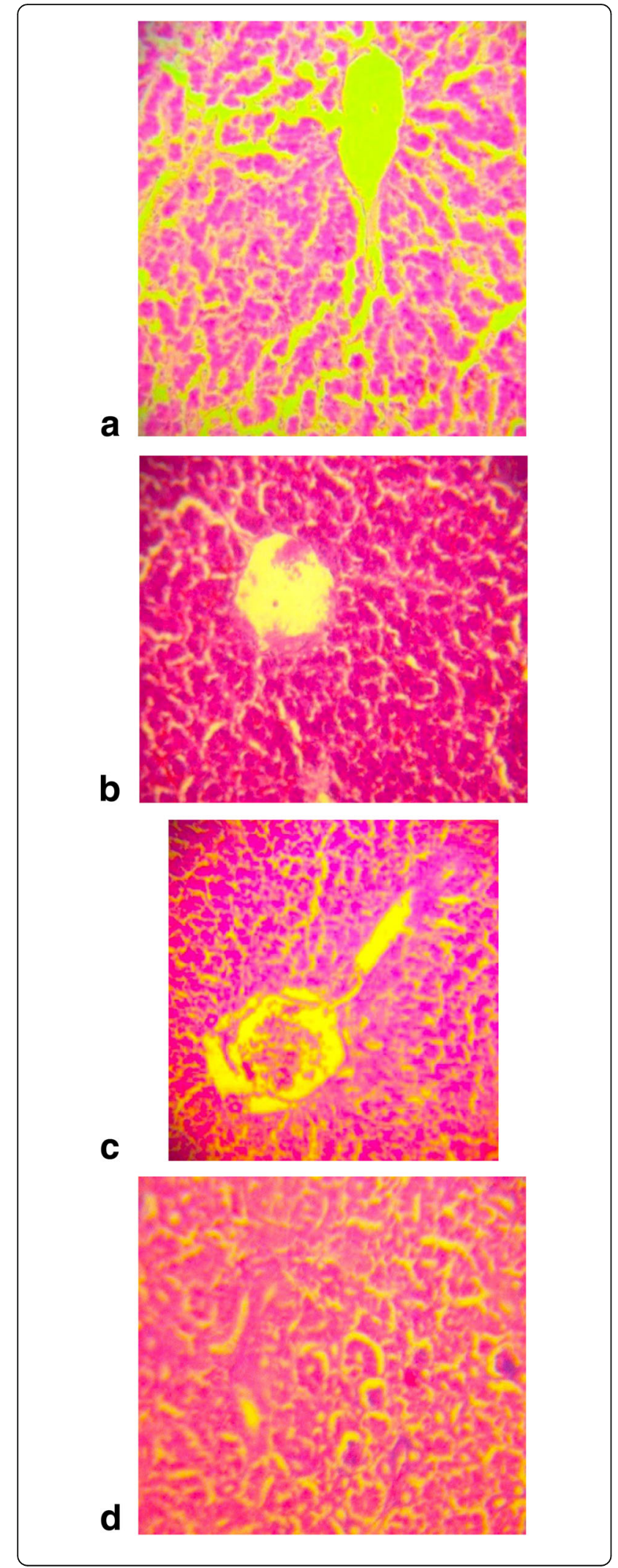

Plate 1 a $\mathrm{H} \times \mathrm{E}$ staining of liver tissue from control group showed normal structure with no evidence of histopathological changes, $x$ 100. $\mathbf{b} \mathrm{H} \times \mathrm{E}$ staining of liver tissue from zinc (low dose) administered broiler chick showed necrosis and liver cell hypertrophy, $\times 100 . \mathbf{c H} \times \mathrm{E}$ staining of liver tissue from zinc (intermediate dose) administered broiler chicks showed fuzzy liver cells, lymphocytic inflammation and liver cell hypertrophy, $\times 100 . \mathbf{d}$ $\mathrm{H} \times \mathrm{E}$ staining of liver tissue from zinc (high dose) administered broiler chicks showed congestion with connective tissue hyperplasia, bile duct proliferation and liver cell hypertrophy, $\times 100$

V. Transferred the slides to a jar containing water.

VI. Transferred the slides in a jar containing haematoxylin for 3-5 min.

VII. Transferred the slide under running water for $5 \mathrm{~min}$.

VIII.Transferred the slide carrier in a jar containing 1\% acid alcohol 70\% for differentiation 3-4 dips (5 to $30 \mathrm{~s}$ ).

IX. Washed under running tap water for 5-10 min.

$\mathrm{X}$. Transferred the slide carrier into a jar containing $1 \%$ eosin for $1 / 2$ to $1 \mathrm{~min}$.

XI. Dehydrated the slide in 2 changes of acetone of 1 min at each change.

XII. Transferred the slide carrier to a jar containing 1:1 xylene:acetone mixture for $1 \mathrm{~min}$.

XIII.Then transferred the slide carrier to a jar containing xylene.

After staining the sections are mounted with DPX (Deoxy Plasticisor Xylene) and microscopical examination was done by using a compound microscope.

\section{Results}

In this study, the effect of high, intermediate and low concentrations of zinc on the histology of the liver of broiler chicks was investigated. Liver of control birds showed normal structure of central vein, hepatic sinusoids, endothelium, portal vein, sinusoids and kupffer cells, which was influenced by the administration of different doses of zinc (Plate 1a). Following exposure to low dose $(300 \mathrm{mg} / \mathrm{kg}$ b.w.) (Plate $1 \mathrm{~b})$, necrosis and liver cell hypertrophy were found in the liver of birds, but the structure of central vein, hepatic sinusoids, endothelium, portal vein, sinusoids and the kupffer cells as compared to their respective control.

Birds exposed to intermediate dose $(600 \mathrm{mg} / \mathrm{kg}$ b.w.) (Plate 1c) of zinc it showed the fuzzy liver cells, lymphocytic inflammation and liver cell hypertrophy as compared to control.

Broiler chicks exposed to high dose ( $900 \mathrm{mg} / \mathrm{kg}$ b.w.) of zinc showed pronounced changes in the liver such as congestion of blood vessels, connective tissue hyperplasia, bile duct proliferation, dilation of sinusoids, damaged intercellular contacts between hepatocytes, liver cell hypertrophy and accumulation of inflammatory cells including heterophiles and lymphocytes in the sinusoids of liver as compared to their respective controls (Plate 1d). These results 
suggest that due to the more accumulation of zinc in the liver of the broiler chicks, the chicks possess more stress and severe histological changes in their liver because the liver is the important site for zinc accumulation.

\section{Discussion}

The liver has the critical job of maintaining the body's metabolic homeostasis. This includes the processing of dietary amino acids, carbohydrates, lipids and vitamins: removal of microbes and toxins in splanchnic blood and route to the systemic circulation; synthesis of many plasma proteins; and detoxification and excretion into the bile of endogenous waste products and pollutants xenobiotics. Zinc is an essential trace element which is necessary for normal functioning of more than 300 enzymes. There are several studies available of oral zinc toxicity which includes various zinc-induced physiological changes in humans and animals, including decreases in the activity of copper metalloenzyme, gastrointestinal effects, haematological effects [7, 11, 17, 21].

Loganathan et al. [16] have been reported in their study that haemorrhage nuclear pyknosis, degeneration of hepatocytes and severe necrosis in the liver of Labeo rohita exposed to zinc.

Supplementation of zinc causes cirrhotic liver that leads to a decrease in collagen, fibrin and reticulin reported by Dashti et al. [6]. Ruqayah Ali Salman [18] reported that the deposition of amyloid-like substance on the wall of liver sinusoids, infiltration of inflammatory cells such as neutrophils and mononuclear cells, congested blood vessels and replacement of hepatic cords deposition in albino male mice exposed to zinc oxide nanoparticles for 15 days. Loss of normal liver arrangement with dilated congested veins, inflammatory cellular infiltration, necrotic foci between hepatocytes, dilated congested portal vein with the proliferation of bile duct and blood sinusoids with large cytoplasmic vacuoles in hepatocytes in rat induced with zinc oxide for five constitutive days orally [1]. Li et al. [15] reported higher egg laying in chickens fed dietary supplementation with additional 24, 48, 72, 96 and $120 \mathrm{mg} \mathrm{Zn/}$ $\mathrm{Kg}$ up to 65 weeks of age. Improvement in the food conversion ratio and significant increase in dietary BMC level and body weight was found in broiler supplemented with photogenic mixture in the diet contained equal ratios of black cumin, Moringa oleifera and chicory seeds [2].

\section{Conclusion}

Zinc is widely used in the poultry industry for the growth of broiler chicks, but in the limited amount. If we use zinc in higher than normal amount than it affects the liver and other organs of the body of the chicks. Therefore, it is necessary to take a normal dose of zinc, which helps to improve the proper growth of the chicks.

\section{Acknowledgements}

I am extremely grateful to Dr. R.K. Singh, CDRI, Lucknow, India, who gave me guidance to carry out my research work.

Authors' contributions

The author(s) read and approved the final manuscript.

Funding

Not applicable

Availability of data and materials

Data sharing not applicable to this article as no datasets were generated or analysed during the current study.

Ethics approval and consent to participate

Animal studies were conducted according to the regulations of the Institute Animal Ethics Committee (IAEC). Registration no.: 34/1999/CPCSEA, ID no.: CDRI-Tox/SYS/2008/01.

Consent for publication

Not applicable

\section{Competing interests}

The authors declare that they have competing interests.

Received: 17 October 2019 Accepted: 19 March 2020

Published online: 10 June 2020

\section{References}

1. Abdelmonem AH, Marwa MA, Mohammed AS, Marwa MA (2018) Changes in rats' liver structure induced by zinc oxide nanoparticles and the possible protective role of Vitamin E. Int J Human Anatomy 1(3):1-16

2. Arif M, Hayat Z, Abd El-Hack ME, Saeed M, Imran HM, Alowaimer AN, Saadeldin IM, Taha AE, Swelum AA (2019) Impacts of supplementing broiler diets with a powder mixture of black cumin, Moringa and chicory seeds. South Afr J Animal Sci 49(3):564-572

3. ATSDR (Agency for Toxic Substances and Disease Registry) (1995) Toxicological profile for zinc. Public Health Service, U.S. Department of Health and Human Services, Atlanta

4. Christensen J, Jensen D, Christensen T (1996) Effect of dissolved organic carbon on the mobility of cadmium, nickel and zinc in leachate polluted groundwater. Water Research 30:3037-3049

5. Chrastinova L, Cobanova K, Chrenkova M, Polacikova M, Foemelova Z, Laukova L, Oondruska A, Pogany SM, Strompfova V, Mlynekova Z, Kalafova A, Gresakova L (2016) Effect of dietary zinc supplementation on nutrients digestibility and fermentation characteristics of caecal content in physiological experiment with young rabbits. Slovak J Anim Sci 49(1):23-31

6. Dashti HM, Mathew TC, Jadaon MM, Ashkanani E (1997) Zinc and liver cirrhosis: biochemical and histopathological assessment. Nutrition 13:206212

7. Davis CD, Milne DB, Nielsen FH (2000) Changes in dietary zinc and copper affect zinc status indicators of postmenopausal women, notably, extracellular superoxide dismutase and amyloid precursor proteins. Am J Clin Nutr 71:781-788

8. Faure P, Roussel A, Coudray C, Richard MJ, Halimi S, Favier A (1992) Zinc and insulin sensitivity. Biological Trace Element Res 32:305-310

9. Gaizer F (1989) Protonation and zinc complex formation of insulin. Polyhedron 8:2065-2070

10. Gao S, Walker W, Dahlgren R (1997) Simultaneous sorption of Cd, Cu, Ni, Zn, $\mathrm{Pb}$, and $\mathrm{Cr}$ on soils treated with sewage sludge supernatant. Water Air and Soil Pollution 93:331-345

11. Hale WE, May FE, Thomas RG (1988) Effect of zinc supplementation on the development of cardiovascular disease in the elderly. J Nutr Elder 8:49-57

12. Handy RD, von der Kammer F, Lead JR, Hassellov M, Owen R, Crane M (2008) The ecotoxicology and chemistry of manufactured nanoparticles. Ecotoxicology 17(4):287-314

13. Lewis RJ Sr (1993) Hawley's condensed chemical dictionary, 12th edn. Van Nostrand Rheinhold Co, New York, p 1242

14. Liao X, Li W, Zhu Y, Zhang L, Lu L, Lin X, Luo X (2018) Effects of environmental temperature and dietary zinc on egg production 
performance, egg quality and antioxidant status and expression of heatshock proteins in tissues of broiler breeders. Br. J. Nutr. 120:3-12

15. Li L, Abouelezz KFM, Gou Z, Lin X, Wang Y, Fan Q, Cheng Z, Ding F, Jiang S, Jiang $Z$ (2019) Optimization of dietary zinc requirement for broiler breeder hens of Chinese yellow-feathered chicken. Animals 9:472

16. Loganathan K, Velmurugan B, Hongray Howrelia J, Selvanayagam M, Patnaik BB (2006) Zinc induced histological changes in brain and liver of Labeo rohita (Ham.). J Environ Biol 27(1):107-110

17. Milne DB, Davis CD, Nielsen FH (2001) Low dietary zinc alters indices of copper function and status in postmenopausal women. Nutrition 17:701708

18. Ruqayah AS (2018) Histopathological effect of zinc oxide nanoparticles on kidney and liver tissue in albino male mice. Ibn Al-Haitham J for Pure and Appl. Sci. 31(1):9-14

19. Sahoo A, Swian RK, Mishra SK, Jena B (2014) Serum biochemical indices of broiler birds fed on inorganic, organic and nono zinc supplementation diets. Int J Recent Scientific Res 5(11):2078-2081

20. Saleki S, Ardalan FA, Javidan-Nejad A (2007) Liver histopathology of fatal phosphine poisoning. Forensic Sci int 166:190-193

21. Samman S, Roberts DC (1988) The effect of zinc supplements on lipoproteins and copper status. Atherosclerosis 70:247-252

22. Saraf V, Pande S, Gopalakrishnan U, Balakrishnan D, Menon RN, Sudheer OV (2015) Acute liver failure due to zinc phosphide containing rodenticide poisoning: clinical features and prognostic indicators of need for liver transplantation. Ind J Gastroenterol 34:325-329

23. Thomas DW (1991) In: Merian E (ed) Metals and their compounds in the environment. VCH, Weinheim, pp 1309-1342

24. Tsai YH, Mao SY, Li MZ, Huang JT, Lien TF (2016) Effects of nano size zinc oxide on zinc retention, eggshell quality, immune response and serum parameters of aged laying hens. Animal Feed Sci Tech 213:99-107

25. Yan R, Zhang L, Yang X, Wen C, Zhou Y (2016) Bioavailability evaluation of zinc-bearing palygorskite as a zinc source for broiler chickens. Applied Clay Science. 119:155-160

\section{Publisher's Note}

Springer Nature remains neutral with regard to jurisdictional claims in published maps and institutional affiliations.

\section{Submit your manuscript to a SpringerOpen ${ }^{\circ}$ journal and benefit from:}

- Convenient online submission

- Rigorous peer review

- Open access: articles freely available online

- High visibility within the field

- Retaining the copyright to your article

Submit your next manuscript at $\boldsymbol{\nabla}$ springeropen.com 